\title{
INDUSTRIALIZATION OF DEVELOPING COUNTRIES IN A MULTICOUNTRY, MULTISECTOR CAPITAL ACCUMULATION MODEL
}

\section{Tadateru Hayashi}

NO. 62

\section{ADB SOUTH ASIA WORKING PAPER SERIES}


ADB South Asia Working Paper Series

\section{Industrialization of Developing Countries in a Multicountry, Multisector Capital Accumulation Model}

Tadateru Hayashi

No. 62 | December 2018
Tadateru Hayashi is principal economist at

Regional Cooperation and Operations Coordination

Division, South Asia Department,

Asian Development Bank (ADB).

The preparation of this paper was motivated by discussions during the preparation of a country partnership strategy for Sri Lanka of the Asian Development Bank. The draft paper was presented at a seminar in the Economic Research and Regional Cooperation Department, ADB on 28 February 2018. The author appreciates the comments received at the seminar, which were incorporated in this working paper. 
(C) 2018 Asian Development Bank 6 ADB Avenue, Mandaluyong City, 1550 Metro Manila, Philippines

Tel +632632 4444; Fax +6326362444

www.adb.org

Some rights reserved. Published in 2018.

ISSN 2313-5867 (print), 2313-5875 (electronic)

Publication Stock No. WPS189783-2

DOI:http://dx.doi.org/10.22617/WPS189783-2

The views expressed in this publication are those of the authors and do not necessarily reflect the views and policies of the Asian Development Bank (ADB) or its Board of Governors or the governments they represent.

ADB does not guarantee the accuracy of the data included in this publication and accepts no responsibility for any consequence of their use. The mention of specific companies or products of manufacturers does not imply that they are endorsed or recommended by ADB in preference to others of a similar nature that are not mentioned.

By making any designation of or reference to a particular territory or geographic area, or by using the term "country" in this document, $A D B$ does not intend to make any judgments as to the legal or other status of any territory or area.

This work is available under the Creative Commons Attribution 3.0 IGO license (CC BY 3.0 IGO)

https://creativecommons.org/licenses/by/3.o/igo/. By using the content of this publication, you agree to be bound by the terms of this license. For attribution, translations, adaptations, and permissions, please read the provisions and terms of use at https://www.adb.org/terms-use\#openaccess.

This CC license does not apply to non-ADB copyright materials in this publication. If the material is attributed to another source, please contact the copyright owner or publisher of that source for permission to reproduce it. $\mathrm{ADB}$ cannot be held liable for any claims that arise as a result of your use of the material.

Please contact pubsmarketing@adb.org if you have questions or comments with respect to content, or if you wish to obtain copyright permission for your intended use that does not fall within these terms, or for permission to use the ADB logo.

The ADB South Asia Working Paper Series is a forum for ongoing and recently completed research and policy studies undertaken in ADB or on its behalf. It is meant to enhance greater understanding of current important economic and development issues in South Asia, promote policy dialogue among stakeholders, and facilitate reforms and development management.

The ADB South Asia Working Paper Series is a quick-disseminating, informal publication whose titles could subsequently be revised for publication as articles in professional journals or chapters in books. The series is maintained by the South Asia Department. The series will be made available on the ADB website and on hard copy.

Notes:

In this publication, “\$” refers to United States dollars.

Corrigenda to ADB publications may be found at http://www.adb.org/publications/corrigenda. 


\section{CONTENTS}

TABLES AND FIGURES IV iv

SUMMARY V v

$\begin{array}{lll}\text { I. INTRODUCTION } & 1\end{array}$

II. LITERATURE REVIEW

III. THE MODEL $\quad 3$

A. Model Setup 3

B. Household Behavior $\quad 3$

C. Firm Behavior $\quad 4$

D. Market Clearing Conditions $\quad 6$

E. Calculation $\quad 6$

$\begin{array}{ll}\text { F. Trade Relations between Two Countries } & 7\end{array}$

$\begin{array}{ll}\text { IV. SOLUTION } & 9\end{array}$

A. Steady State $\quad 9$

$\begin{array}{ll}\text { B. Convergence } & 10\end{array}$

V. NUMERICAL EXAMPLES

$\begin{array}{ll}\text { VI. INTRODUCTION OF INTERNATIONAL CAPITAL MOBILITY } & 15\end{array}$

$\begin{array}{ll}\text { VII. CONCLUSIONS } & 17\end{array}$

$\begin{array}{lr}\text { REFERENCES } & 18\end{array}$

APPENDIX: RELATIONSHIP BETWEEN VARIETIES AND SYNTHETIC GOODS 19 


\section{TABLES AND FIGURES}

\section{TABLES}

1 Status of Economy at Steady State 13

2 Status of Economy at Steady State (With International Capital Mobility) 16

\section{FIGURES}

1 Trade Relations (Factor Prices Equalization Case) 8

2 Trade Relations (Production Specialization Case) 8

3 Three Cases of Production Specialization 9

4 Convergence Paths of Capital per Labor (Specialization Case) 12

5 Dynamics of Economic Variables During Convergence (Specialization Case) 13

6 Image of Industrialization of Developing Country 14

7 Convergence Paths of Capital per Labor (With International Capital Mobility) 16

8 Status of Economy at Steady State (With International Capital Mobility) 17 


\section{SUMMARY}

This paper shows that industrialization of developing countries, defined as start of production of investment goods, happens when their share in global production exceeds the global demand for consumption goods. Industrialization is simulated in a capital accumulation model with two countries (advanced and developing), three goods, and two factors. The model accommodates trade relations where countries specialize in the production of one or two goods, which happens when countries have relatively different factor endowments. The model includes production under monopolistic competition and with intermediate inputs. Capital mobility across the border can facilitate industrialization, but the developing country continues borrowing capital from the advanced country at the steady state where capital accumulation stops. The model also shows that a gap in per labor capital between countries narrows, but the developing country never catches up with the advanced country. Gaps between the countries are smaller in per labor gross domestic product and consumption, than in per labor capital.

\section{KEY WORDS}

industrialization, capital accumulation, multicountry, multisector, growth model

\section{JEL Classification Codes}

F43, O14, O41 



\section{INTRODUCTION}

1. This paper aims to answer the question of whether a developing country, which is currently producing labor-intensive consumption goods, should promote the production of capital-intensive investment goods to sustain its economic growth. Such start of production of investment goods is defined as industrialization in this paper. Industrialization has been central to development strategies in many economies. Hong Kong, China; the Republic of Korea; Singapore; Taipei,China; and, recently, the People's Republic of China promoted manufacturing and successfully upgraded their income level. Now, developing countries question if they should also promote manufacturing and industrialize their country to sustain their economic development; more fundamentally, if they still have a chance to produce investment goods given that the above East Asian countries have already developed a large manufacturing base.

2. This paper provides a framework to analyze the industrialization of a developing country in a multicountry multisector model. The model assumes capital accumulation with endogenous savings based on the theory by Ramsey-Cass-Koopmans. International trade is driven by difference in factor endowment following Heckscher-Ohlin theory. The paper however accommodates the case where countries specialize in producing a particular set of goods. This happens when countries have relatively different factor endowments, commonly observed between developing and advanced economies. In such cases, factor prices do not equalize among the countries through trade. The model also includes production under monopolistic competition for capital-intensive goods, and intermediate inputs to model input-output relations. The model generates numerical examples of capital accumulation to observe behavior of the model. During the convergence towards steady states, the model can generate cases where a developing country starts production of investment goods.

3. The rest of the paper is structured as follows. Section II provides a literature review on economic growth with international trade. Section III formulates the capital accumulation model, section IV deals with solutions, and section $\mathrm{V}$ provides outcomes of the model using numerical examples. Section $\mathrm{VI}$ introduces international capital mobility into the model, and section VII concludes.

\section{LITERATURE REVIEW}

4. Research studies have found that in a global economy with multiple countries do not converge to a steady state with equal per capita income. The studies used models which combined economic growth and international trade.

5. Chen (1992) found that a country with larger initial capital-labor ratio will continue to have the higher ratio, and hence will maintain higher per capita income. He developed a multisector growth model with endogenous capital accumulation and consumer intertemporal optimization (RamseyCass-Koopmans model) with two countries, two traded goods, and two non-traded inputs ( $2 \times 2 \times 2)$, which he called a dynamic Heckscher-Ohlin model. He also made labor supply endogenous in his model. Parameters are identical in two countries, but the initial capital-labor ratio. Chen explained that the difference in capital-labor ratio will not be narrowed because factor prices are equalized through international trade, and hence two countries face same return on capital.

6. Trefler (1993) explained the difference of income level by different labor efficiency. He showed that factor price equalization holds once labor endowment is adjusted with its efficiency. However, factor prices without the adjustments differ among countries, which causes difference in capital accumulation. As such, countries with high labor efficiency can achieve higher income. 
7. Ventura (1997) showed that different technology makes variance in labor efficiency, and hence generates convergence to different income levels. His model includes a non-traded final goods for both consumption and investment, which is produced with two traded intermediate goods, of which one is produced with capital while the other by labor.

8. Atkeson and Kehoe (2000) emphasized that the timing of development determines a country's long-term income level. A small country that begins its economic development when other economies have already reached steady states accumulates its capital until it arrives at the cone of diversification (where factor prices equalized with other countries). At the edge of the cone, the small country specializes in labor-intensive goods. Capital accumulation in the small country stops at the edge as rental rate of capital is equal to the rest of the world. Now the small economy produces only labor-intensive goods, while other economies produce both capital- and labor-intensive goods. Therefore, the income level of the small country stays lower than that of the rest of the world.

9. Deardorff (2002) developed a concept of multiple cones of diversification to analyze the case where factor prices do not equalize through trade. Factor price equalization holds only when factor endowments of two countries are not so different and located within a cone of diversification. However, if factor endowments between developing and advanced countries are quite different, factor prices do not become the same through trade. In such cases, countries specialize in producing a particular set of goods. Deardorff introduced two countries, three goods, and two factor model $(2 \times 3 \times 2)$, which allowed two cones of diversification. Schott (2003) tested one versus multiple cone models with sample data including both advanced and developing countries. He rejected one cone model, while multiple cone model fitted well.

10. Cuñat and Maffezzoli (2004) proposed a growth model with international trade where countries specialize, and factor prices do not equalize. The model included two countries, three goods, and two factors $(2 \times 3 \times 2)$. It showed that the global economy under specialized trade relations will grow towards factor price equalization. Consistent with other papers, a country which initially has smaller per labour capital (capital-labor ratio) will converge to a steady state with less per capita income. The other country with larger per capita capital converges to a steady state with higher per capita income. The paper also investigated a many country case, where richer economies in developing country group will almost catch up with the poorest economy in the advanced economy group. The model however simplified production technology of goods, so that it does not allow countries to start production of other goods. Production of most labor-intensive goods is assumed to require only labor inputs, while that of most capital-intensive goods requires capital inputs only. The goods with medium intensity of labor and capital can be produced in both countries, and the share of its production in each country is the only way to show structural change in production.

11. Bajona and Kehoe (2006 and 2010) indicated convergence to different income levels in different model settings. They used a dynamic Heckscher-Ohlin model with $\mathrm{n}$ countries, 3 goods (one non-traded investment good and two traded goods, which can be consumed or invested), and 2 factor inputs $(n \times 3 \times 2)$. Income levels of countries, whose initial per capita capital endowment differs, converge or diverges, depending on the elasticity of substitution between the traded goods. Factor price equalization at earlier stage of development does not imply factor price equalization in future periods.

12. Gaitan and Roe (2007) reiterated that per labor capital stock of two countries accumulates to different levels, depending on their initial endowment under $2 \times 2 \times 2$ dynamic Heckscher-Ohlin model with exogenous labor supply settings. Gaitan and Roe formulated an algebraic model and presented numerical simulation examples. The analysis is however limited to factor price equalization case, i.e., endowments of countries located within cone of diversification. 
13. So far, many studies focused on factor price equalization case. However, a model for specialization case is essential to analyze the industrialization of a developing country. Bajona and Kehoe attempted to develop such model, but strong assumption in the model does not allow analysis of industrialization. Therefore, the next section develops a more general capital accumulation model with international trade, including the specialized trade relations, which allows analysis of industrialization. The model also includes monopolistic competition in the production of most capital-intensive goods, and intermediate inputs in the production of less capital-intensive goods. Later, the model will allow the case of international transfer of capital.

\section{THE MODEL}

\section{A. Model Setup}

14. The model assumes a global economy with two countries, three goods, and two factors $(2 \times 3 \times 2)$. Country 1 is relatively capital abundant (advanced country), while country 2 is relatively capital scarce (developing country). Three goods are produced: goods $x$ is intermediate goods, goods $y$ is investment goods, and goods $c$ is consumption goods. Goods $x$ is produced under monopolistic competition, and synthetic goods of its varieties is used as intermediate inputs for production of goods $y$ and goods $c$. The relationship between the supplies of synthetic goods $\left(Y_{x}\right)$ and its varieties $\left(Y_{x i}\right)$ is defined in the constant elasticity of substitution function in equation (1) below. Goods $y$ and goods $c$ are produced under perfect competition market.

$$
Y_{x}=\left(\int_{0}^{n} Y_{x i}{ }^{\sigma} d i\right)^{\frac{1}{\sigma}}
$$

where $n$ is the number of varieties (which is equal to the number of firms because of increasing return to scale in production), and $\sigma$ is preference for variety by intermediate goods users.

Prices of the synthetic intermediate goods is $p_{x}$ and that of goods $y$ is $p_{y}$. Goods $c$ is a numeraire. All of three goods are traded, so the prices will be the same among the countries (free and costless trade is assumed). Two factors, capital $(K)$ and labor $(L)$, are used to produce goods $x, y$ and $c$ together with the intermediate inputs for goods $y$, and $c$. Factor cost for $K$ and $L$ of country j are described as $r_{j}$ and $w_{j}$, respectively. Factors are mobile between sectors in a country, but cannot move across the border. There will be no international borrowing and lending, and thus trade will be balanced in each period (this assumption will be relaxed later). Labor endowments ( $L_{1}$ and $\left.L_{2}\right)$ are exogenously given.

\section{B. Household Behavior}

15. Households maximize their intertemporal utility generated by consumption subject to budget constraint. This determines their allocation of income into consumption and savings (investment). Countries 1 and 2 have identical $\theta$ utility function as described below, characterized with a constant elasticity of intertemporal substitution $\theta(\theta>0$ and $\theta \neq 1)$.

$$
\mathrm{U}\left(c_{j}\right)=\frac{c_{j}^{1-\theta}}{1-\theta} \quad(j=1,2)
$$

$c_{j}$ is consumption of households in country $j$. It is a function of time, but the suffix for time is omitted for the time being to make the equations simple (same for other variables). The utility maximization problem is described below with a discount rate of $\rho>0 . \delta$ is the depreciation rate of capital. 


$$
\max \int_{0}^{\infty} U\left(c_{j}\right) * e^{-\rho t} d t \quad \text { s.t. } \quad \dot{K}_{J}=\frac{\left(r_{j}-\delta * p_{y}\right) * K_{j}+w_{j} * L_{j}-c_{j}}{p_{y}}
$$

The first order conditions of the maximization problem and the transversality conditions are given as follows.

$$
\begin{gathered}
c_{j}^{-\theta}=\frac{\lambda_{j}}{p_{y}} \\
\lambda_{j} *\left(\frac{r_{j}}{p_{y}}-\delta-\rho\right)=-\dot{\lambda}_{j} \\
\lim _{t \rightarrow \infty} \lambda_{j} * K_{j} * e^{-\rho t}=0
\end{gathered}
$$

where $\lambda_{j}$ is the co-state variable in the Hamiltonian to solve the maximization problem.

Thus, the following equations of the household behavior is derived.

$$
\frac{\dot{c_{J}}}{c_{j}}=\frac{1}{\theta} *\left(-\frac{\dot{\lambda_{J}}}{\lambda_{j}}+\frac{\dot{p_{y}}}{p_{y}}\right)=\frac{1}{\theta} *\left(\frac{r_{j}}{p_{y}}+\frac{\dot{p_{y}}}{p_{y}}-\delta-\rho\right)
$$

\section{Firm Behavior}

16. Production of consumption and investment goods ( $y$ and $c$ ) requires value addition and intermediate goods following Leontief production function. Value addition is generated by capital and labor inputs, which follows Cobb-Douglas production function. Production of intermediate goods $x$ uses more capital than goods $y$, and production of goods $c$ uses more labor than goods $y$. Accordingly, goods $x$ is the most capital intensive followed by goods $y$, and goods $c$ is the most labor intensive. There is no difference in technology in countries 1 and 2. Technology is assumed to be same over time.

17. Goods $x$ is produced under monopolistic competition market. The production function of firm $i$ is given in equation (8) (suffix to indicate country $j$ is omitted to simplify the equation). $Y_{x i}$ is supply of variety $i$ of goods $x, K_{x i}$ and $L_{x i}$ are demand for capital and labor inputs required for producing the variety $i$, and $K_{0}$ and $L_{0}$ are fixed inputs.

$$
Y_{x i}=\left(K_{x i}-K_{0}\right)^{\alpha} *\left(L_{x i}-L_{0}\right)^{1-\alpha}
$$

where $0<\alpha<1$

Follow the first order conditions for profit maximization problem and eliminate the element of goods prices. By inserting the derived into the production function, following firm-level factor demand functions are obtained.

$$
\begin{aligned}
K_{x i} & =\left(\frac{\alpha}{1-\alpha} * \frac{w}{r}\right)^{1-\alpha} * Y_{x i}+K_{0} \\
L_{x i} & =\left(\frac{\alpha}{1-\alpha} * \frac{w}{r}\right)^{-\alpha} * Y_{x i}+L_{0}
\end{aligned}
$$

Next, rewrite the profit function by inserting the above factor demand functions.

$$
\pi_{x i}=p_{x i} * Y_{x i}-\frac{r^{\alpha} * w^{1-\alpha}}{\alpha^{\alpha} *(1-\alpha)^{(1-\alpha)}} * Y_{x i}-\left(r * K_{x 0}+w * L_{x 0}\right)
$$


Taking the first order condition $\partial \pi_{x i} / \partial p_{x i}=0$ and insert equation (A7) from the Appendix,

$$
p_{x i}=\frac{1}{\sigma} * \frac{r^{\alpha} * w^{1-\alpha}}{\alpha^{\alpha} *(1-\alpha)^{(1-\alpha)}}
$$

It is assumed that there is free entry and exist of firms to produce varieties of goods $x$. Therefore, profit of the firms for available varieties will be zero $\left(\pi_{x i}=0\right)$. Therefore, from equations (11) and (12), supply of variety $x_{i}$ is given as below.

$$
Y_{x i}=\left(r * K_{0}+w * L_{0}\right) /\left\{\frac{1-\sigma}{\sigma} * \frac{r^{\alpha} * w^{1-\alpha}}{\alpha^{\alpha} *(1-\alpha)^{(1-\alpha)}}\right\}
$$

This shows that supply of varieties is same for every active firms (indicate it as $Y_{x i}^{*}$ ). Therefore, the relationship between the supply of synthetic goods and varieties in equation (1) can be simplified as follows.

$$
Y_{x}=n^{1 / \sigma} * Y_{x i}^{*}
$$

Using equation (A6) in the Appendix, relationship between the price index of synthetic goods and prices of varieties will be

$$
p_{x}=n^{\sigma-1 / \sigma} * p_{x i}
$$

Applying the above equation (14) and $K_{x}=n * K_{x i}$ and $L_{x}=n * L_{x i}$, demand functions for factor inputs (9)-(10) can be rewritten as below (suffix for country $\mathrm{j}=1,2$ is revived).

$$
\begin{gathered}
K_{x j}=n_{j}{ }^{(\sigma-1) / \sigma} *\left(\frac{\alpha}{1-\alpha} * \frac{w_{j}}{r_{j}}\right)^{1-\alpha} * Y_{x j}+n_{j} * K_{0} \\
L_{x j}=n_{j}(\sigma-1) / \sigma *\left(\frac{\alpha}{1-\alpha} * \frac{w_{j}}{r_{j}}\right)^{-\alpha} * Y_{x j}+n_{j} * L_{0}
\end{gathered}
$$

Inserting equation (15) into (12) will give the following relationship:

$$
p_{x}=n^{\sigma-1 / \sigma} * \frac{1}{\sigma} * \frac{r^{\alpha} * w^{1-\alpha}}{\alpha^{\alpha} *(1-\alpha)^{(1-\alpha)}}
$$

18. Goods $y$ and $c$ are produced under perfect competition with capital and labor inputs as well as intermediate goods. Production functions are given as below with $x_{y j}$ and $x_{c j}$ being demand for intermediate goods $x$. Since production of these goods are under perfect competition, these equations represent production function of all firms in each sector.

$$
\begin{gathered}
Y_{y j}=\min \left\{\varphi * K_{y j}{ }^{\beta} * L_{y j}{ }^{1-\beta}, \psi * x_{y j}\right\} \\
Y_{c j}=\min \left\{\varphi * K_{c j}{ }^{\gamma} * L_{c j}{ }^{1-\gamma}, \psi * x_{c j}\right\} \\
\text { where } 0<\gamma<\beta<\alpha<1,0<\varphi, 0<\psi
\end{gathered}
$$

From the corner solution, the Leontief production functions can be rewritten as follows.

$$
\begin{gathered}
Y_{y j}=\varphi * K_{y j}{ }^{\beta} * L_{y j}{ }^{1-\beta}=\psi * x_{y j} \\
Y_{c j}=\varphi *{K_{c j}}^{\gamma} * L_{c j}{ }^{1-\gamma}=\psi * x_{c j}
\end{gathered}
$$


Using equations (21) and (22), profit functions can be written as below.

$$
\begin{aligned}
\pi_{y j}=p_{y} * Y_{y j}-\left(r * K_{y j}+w * L_{y j}+p_{x} * x_{y j}\right) & \\
= & \left(p_{y}-\frac{p_{x}}{\psi}\right) * \varphi * K_{y j}{ }^{\beta} * L_{y j}{ }^{1-\beta}-\left(r * K_{y j}+w * L_{y j}\right) \\
\pi_{c j}=Y_{c j}-\left(r * K_{c j}+w * L_{c j}+\right. & \left.p_{x} * x_{c j}\right) \\
& =\left(1-\frac{p_{x}}{\psi}\right) * \varphi *{K_{c j}}^{\gamma} * L_{c j}{ }^{1-\gamma}-\left(r * K_{c j}+w * L_{c j}\right)
\end{aligned}
$$

Maximization of profit in each sector derives the following standard factor demand functions with goods prices.

$$
\begin{aligned}
K_{y j}=\left(p_{y}-\frac{p_{x}}{\psi}\right) * \frac{\beta}{r_{j}} * Y_{y j} & , & L_{y j}=\left(p_{y}-\frac{p_{x}}{\psi}\right) * \frac{(1-\beta)}{w_{j}} * Y_{y j} \\
K_{c j}=\left(1-\frac{p_{x}}{\psi}\right) * \frac{\gamma}{r_{j}} * Y_{c j} & , & L_{c j}=\left(1-\frac{p_{x}}{\psi}\right) * \frac{(1-\gamma)}{w_{j}} * Y_{c j}
\end{aligned}
$$

\section{Market Clearing Conditions}

19. Market clearing conditions hold for factors and goods. Since factors are not traded internationally, each country has its clearing conditions.

$$
\begin{gathered}
K_{x j}+K_{y j}+K_{c j}=K_{j} \\
L_{x j}+L_{y j}+L_{c j}=L_{j}
\end{gathered}
$$

20. Market clearing conditions for goods are as shown in equations (29), (30), and (31). Since goods are traded, there are global clearing conditions for each goods.

$$
\begin{gathered}
Y_{x 1}+Y_{x 2}=x_{y 1}+x_{c 1}+x_{y 2}+x_{c 2} \\
Y_{y 1}+Y_{y 2}=y_{1}+y_{2} \\
Y_{c 1}+Y_{c 2}=c_{1}+c_{2}
\end{gathered}
$$

where $y_{j}=\delta * K_{j}$

Using the intermediate input relations in equations (21) and (22), demand for synthetic goods $x$ can be transformed into the following.

$$
x_{j}=\frac{1}{\psi} *\left(Y_{y j}+Y_{c j}\right)
$$

\section{E. Calculation}

21. The following equation will be obtained for the synthetic goods $x$ by taking natural log of equation (18).

$$
\alpha * \ln r_{j}+(1-\alpha) * \ln w_{j}=\ln A+\ln p_{x}+\ln \sigma-\frac{\sigma-1}{\sigma} * \ln n
$$

$$
\text { where } \mathrm{A}=\alpha^{\alpha} *(1-\alpha)^{1-\alpha}
$$


As for goods $y$ and $c$, insert factor demand functions (25)-(26) into production functions (21)-(22), and taking natural log gives us the following equations.

$$
\begin{aligned}
& \beta * \ln r_{j}+(1-\beta) * \ln w_{j}=\ln B+\ln \left(p_{y}-\frac{p_{x}}{\psi}\right)+\ln \varphi \\
& \gamma * \ln r_{j}+(1-\gamma) * \ln w_{j}=\ln C+\ln \left(1-\frac{p_{x}}{\psi}\right)+\ln \varphi \\
& \text { where } \mathrm{B}=\beta^{\beta} *(1-\beta)^{1-\beta} \text { and } C=\gamma^{\gamma} *(1-\gamma)^{1-\gamma}
\end{aligned}
$$

22. On the other hand, inserting factor demand functions (16)-(17) and (25)-(26) into the factor market clearing conditions (27)-(28) will provide the following equations.

$$
\begin{aligned}
n_{j}^{\frac{\sigma-1}{\sigma}} *\left(\frac{\alpha}{1-\alpha} * \frac{w_{j}}{r_{j}}\right)^{1-\alpha} * Y_{x j}+n_{j} * K_{0}+\left(p_{y}-\frac{p_{x}}{\psi}\right) * \frac{\beta}{r_{j}} * Y_{y j} & +\left(1-\frac{p_{x}}{\psi}\right) * \frac{\gamma}{r_{j}} * Y_{c j}=K_{j} \\
& +(1-\beta) \\
n_{j}^{\frac{\sigma-1}{\sigma}} *\left(\frac{\alpha}{1-\alpha} * \frac{w_{j}}{r_{j}}\right)^{-\alpha} * Y_{x j}+n_{j} * L_{0}+\left(p_{y}-\frac{p_{x}}{\psi}\right) * & \frac{\left(1-\frac{p_{x}}{\psi}\right) * \frac{(1-\gamma)}{w_{j}} * Y_{c j}=L_{j}}{}
\end{aligned}
$$

\section{F. Trade Relations between Two Countries}

23. There are four cases of trade relations between countries 1 and 2 in the model: a case where factor prices equalize, in which case production mix of countries are not determined; and three specialization cases where factor prices differ between the countries and production in the countries focuses on one or two goods. With the production functions defined in equations (8), (19), and (20), expansion paths of goods $x, y$, and $c$ in country $j$ can be drawn as straight dotted lines (Figure 1, left). Note that the expansion path for goods $x$ does not start from the origin because of fixed factor inputs required. Edgeworth box diagram combines the expansion paths in both countries (Figure 1, right). If a combination of factor endowment is located within the space between the expansion paths (cones of diversification) of goods $x$ and $c$ (such as point $\mathrm{E}$ ), both countries will face the same factor prices. Each country produces a combination of goods $x, y$, and $c$. Since production of all goods faces the same factor prices in a country, factor input requirements for goods production are determined at the tangents of isoquants of three goods with a single cost line (Figure 1, left).

24. If the combination of factor endowments is located outside the cones of diversification (such as point E' in Figure 2 right), countries do not face the same factor prices. This is a case where factor prices do not equalize through trade. Goods $y$ has different expansion paths in countries 1 and 2 (Figure 2 left), which separates the cone of diversification into two. Cost lines are also different between the two countries. Country 1 specializes in production of mix of goods $x$ and $y$, and country 2 in goods $y$ and $c$.

25. Following relative capital abundance, country 1 tends to produce capital-intensive goods and country 2 produces labor-intensive goods. Therefore, there are three cases of specialization (Figure 3 ) - country 1 produces goods $x, y$, and $c$, while country 2 produces goods $c$ (case 1); country 1 produces goods $x$ and $y$, while country 2 produces goods $y$, and $c$ (case 2); and country 1 produces goods $x$ while country 2 produces goods $x, y$, and $c$ (case 3 ). 
Figure 1: Trade Relations (Factor Prices Equalization Case)

$\mathrm{Kj}$

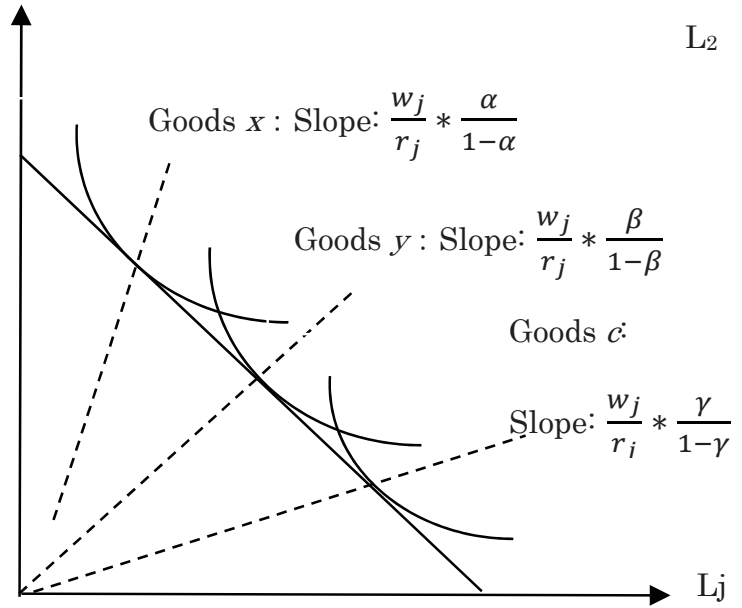

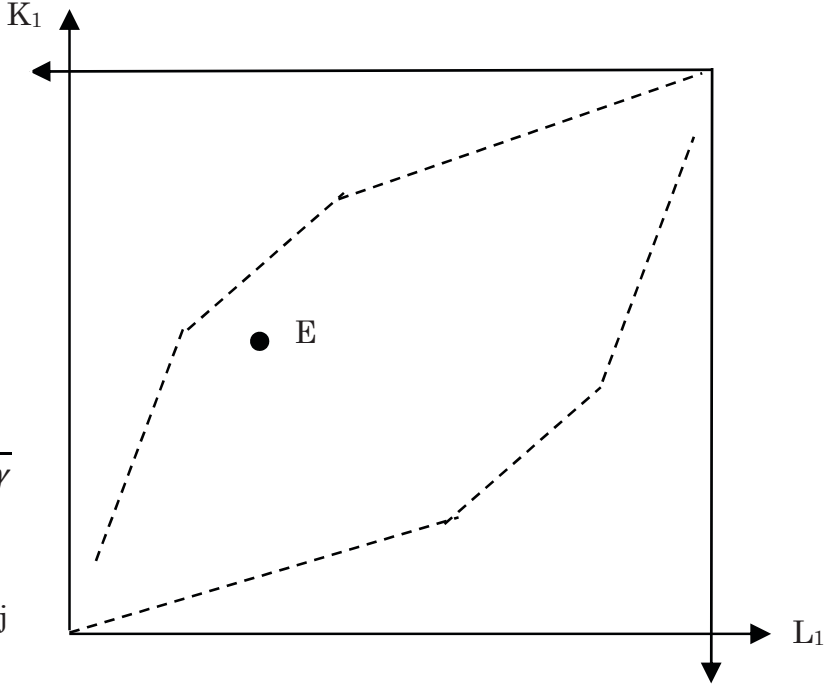

$\mathrm{K}_{2}$

Source: Author.

Figure 2: Trade Relations (Production Specialization Case)

$\mathrm{K}$

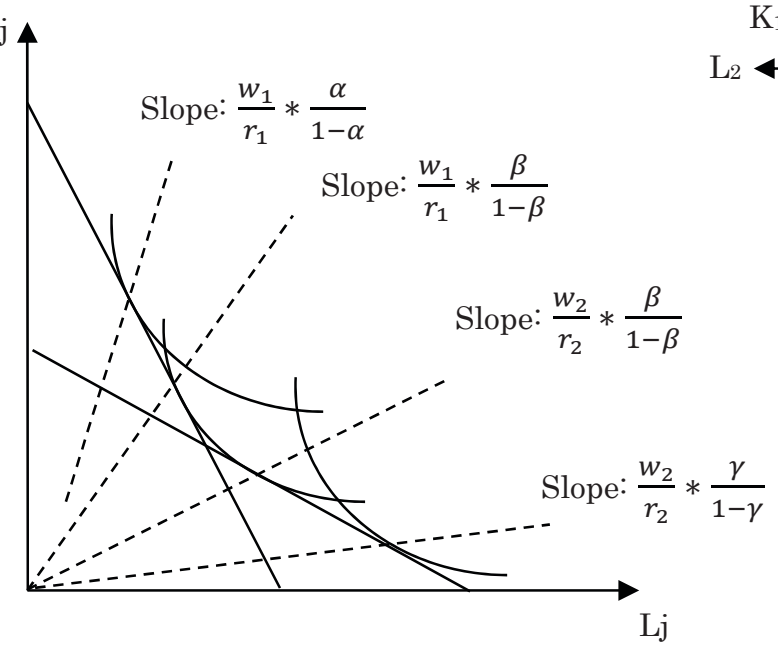

Source: Author.

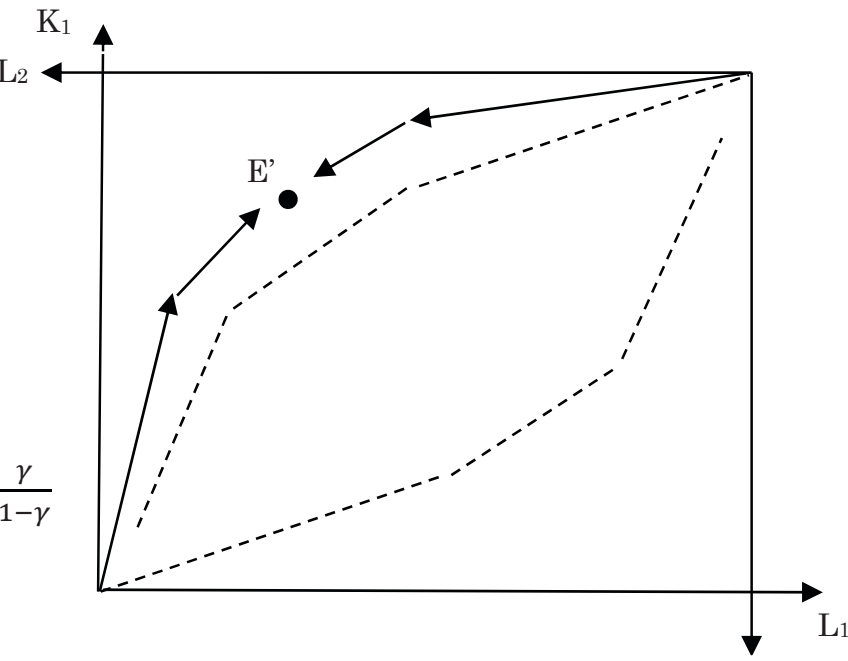




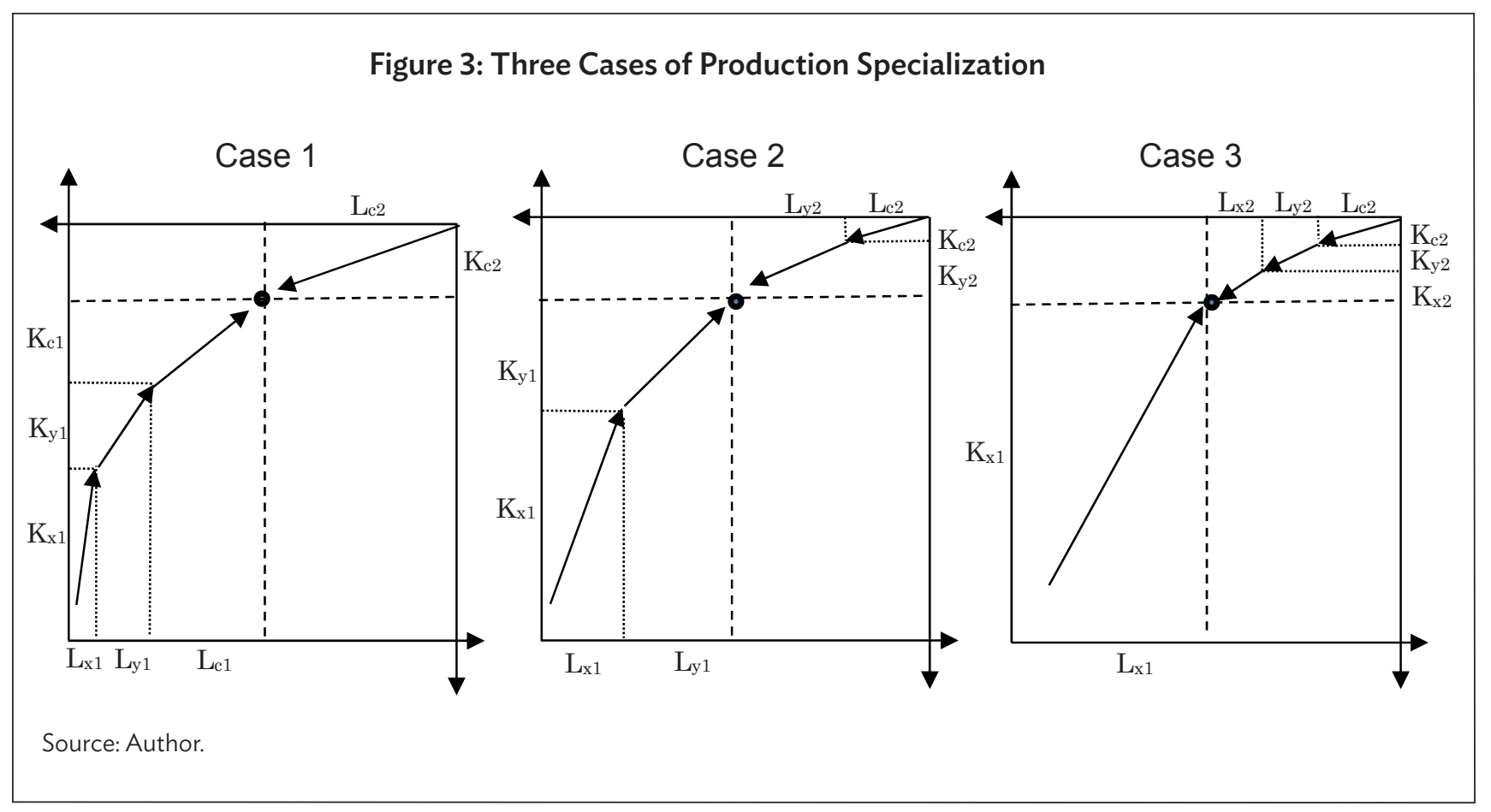

\section{SOLUTION}

\section{A. Steady State}

26. Since $\dot{c}_{j}=0$ and $\dot{p}_{y}=0$ at the steady state, the following relationship is derived from equation (7).

$$
\frac{r_{1}}{p_{y}}=\frac{r_{2}}{p_{y}}=\delta+\rho
$$

The equation shows that capital prices equalize $\left(r_{1}=r_{2}=r\right)$ between two countries at the steady state. Labor prices in both countries will also be the same $\left(w_{1}=w_{2}=w\right)$ to hold the equations (33)-(35). Therefore, factor price equalization holds at the steady state. Further, since $K_{j}=0$ at the steady state, following can be derived from constraint equation in (3).

$$
c_{j}=\left(r_{j}-\delta * p_{y}\right) * K_{j}+w_{j} * L_{j}
$$

Equations (32)-(39) are not sufficient to solve variables for each country, i.e., $\mathrm{r}, \mathrm{w}, p_{x}, p_{y}, Y_{x 1}, Y_{x 2}, Y_{y 1}, Y_{y 2}, Y_{c 1}, Y_{c 2}, n, K_{1}$, and $K_{2}$. Therefore, instead of solving each quantity variables, their global aggregate will be calculated. Adding equations (36)-(37) for countries 1 and 2 will provide the following equations.

$$
\begin{aligned}
\left(n_{1}+n_{2}\right)^{\frac{\sigma-1}{\sigma}} * & \left(\frac{\alpha}{1-\alpha} * \frac{w}{r}\right)^{1-\alpha} *\left(Y_{x 1}+Y_{x 2}\right)+\left(n_{1}+n_{2}\right) * K_{0}+\left(p_{y}-\frac{p_{x}}{\psi}\right) * \frac{\beta}{r} *\left(Y_{y 1}+Y_{y 2}\right) \\
& +\left(1-\frac{p_{x}}{\psi}\right) * \frac{\gamma}{r} *\left(Y_{c 1}+Y_{c 2}\right)=\left(K_{1}+K_{2}\right) \\
\left(n_{1}+n_{2}\right)^{\frac{\sigma-1}{\sigma}} * & \left(\frac{\alpha}{1-\alpha} * \frac{w}{r}\right)^{-\alpha} *\left(Y_{x 1}+Y_{x 2}\right)+\left(n_{1}+n_{2}\right) * L_{0}+\left(p_{y}-\frac{p_{x}}{\psi}\right) * \frac{(1-\beta)}{w} *\left(Y_{y 1}\right. \\
& +Y_{y 2}+\left(1-\frac{p_{x}}{\psi}\right) * \frac{(1-\gamma)}{w} *\left(Y_{c 1}+Y_{c 2}\right)=\left(L_{1}+L_{2}\right)
\end{aligned}
$$


Similarly, equation (32) will become as follows with demand for goods $x$ replaced with supply by the market clearing condition.

$$
Y_{x 1}+Y_{x 2}=\frac{1}{\psi} *\left(Y_{y 1}+Y_{y 2}\right)+\frac{1}{\psi} *\left(Y_{c 1}+Y_{c 2}\right)
$$

Equation (39) will become as follows with consumption goods demand replaced with consumption goods supply by the market clearing condition.

$$
Y_{c 1}+Y_{c 2}=\left(r-\rho * p_{y}\right) *\left(K_{1}+K_{2}\right)+w *\left(L_{1}+L_{2}\right)
$$

Finally, the number of variety of firms is given as below by equations (13) and (14).

$$
\left(n_{1}+n_{2}\right)^{1 / \sigma}=\left(Y_{x 1}+Y_{x 2}\right) *\left\{\frac{1-\sigma}{\sigma} * \frac{r^{\alpha} * w^{1-\alpha}}{\alpha^{\alpha} *(1-\alpha)^{(1-\alpha)}}\right\} /\left(r * K_{0}+w * L_{0}\right)
$$

Now, the equation system (33)-(35), (38), and (40)-(44) can be solved for prices, $n_{1}+n_{2}$, and global supply of goods $Y_{x 1}+Y_{x 2}, Y_{y 1}+Y_{y 2}$, and $Y_{c 1}+Y_{c 2}$ and global capital stock $K_{1}+K_{2}$.

27. The solution of $\left(K_{1}+K_{2}\right)$ shows that steady state consists of combinations of $K_{1}$ and $K_{2}$ (steady state line). Because the global volume of capital stock is fixed, higher capital stock of a county at the steady state means lower capital stock in the other. Global volume of consumption is fixed as well, hence the higher consumption level of a country lowers that of the other. The steady state line has upper and lower boundaries. The upper boundary is where capital-labor ratio in both countries are equal which comes from the assumption that country 1 is capital abundant and country 2 is labor abundant. The lower boundary is determined by maximum $K_{1}$ and minimum $K_{2}$ where factor price equalize.

\section{B. Convergence}

28. Convergence trajectories on saddle paths are calculated backwards from the steady state line. Intertemporal relation for capital accumulation is given by constraint equation in (3) and for $\lambda_{j}$ (which corresponds to consumption) in equation (5). These are converted from continuous to discrete format shown in equations (45) and (46) (suffix for time is added). Note that the capital stock $K_{t}$ is defined as the volume as of end of the period $t$.

$$
\begin{gathered}
K_{j, t-1}=\frac{c_{j, t}-\left\{r_{j, t}-(\delta+1) * p_{y, t}\right\} * K_{j, t}+w_{j, t} * L_{j, t}}{p_{y, t}} \\
\lambda_{j, t-1}=\left(\frac{r_{j, t}}{p_{y, t}}-\delta-\rho+1\right) * \lambda_{j, t}
\end{gathered}
$$

29. Now, choose a combination of capital endowment $\left(K_{1}, K_{2}\right)$ on the steady state line, and calculate a set of prices and quantities. Then, decrease $K_{1}$ and/or $K_{2}$ slightly and recalculate a set of prices and quantities (define this as time $t$ ). Capital stock and consumption level at time $t-1$ are given by the equations (45)-(46). Price and quantity variables are again calculated by the system of equations for time $t-1$. Continue the process until one of the $K_{j}$ reaches zero.

30. Corresponding to the trade relations, there are four types of equations systems:

(i) Factor prices equalization case. With capital stock and consumption demand are decided by their intertemporal relationship, the global supply for consumption and investment goods are given. Supply for goods $c$ and $y$ decides demand for intermediate goods $x$ given the number for $n$. Variables $r, \mathrm{w}, p_{x}$, and $p_{y}$ are determined by equations (33)-(35) and equation (40) [or (41)]. 
(ii) Specialization case 1 . Country 1 produces goods $x, y$, and $c$, while country 2 produces goods $c$ only. Therefore, $Y_{x 2}=0$ and $Y_{y 2}=0$. All of $L_{2}$ is used for goods $c$ production $\left(L_{c 2}=L_{2}\right)$; hence, $Y_{c 2}$ is determined using linear relations between labor input and production. ' Since demand for goods $c$ is given $\left(c_{1}+c_{2}\right), Y_{c 1}$ is decided as a balance, which determines $L_{c 1}$. Since goods $y$ is produced only in country 1 , its demand $\left(y_{1}+y_{2}\right)$ determines $Y_{y 1}$ and $L_{y 1}$. The balance of $L_{1}$ provides us $L_{x 1}$ which determines $Y_{x 1}$ given a number of $n$. Variables $r_{1}, r_{2}, w_{1}, w_{2}, p_{x}$, and $p_{y}$ are determined by equations (33)-(34) for $j=1$, equation (35) for $j=1,2$, and equation (36) $[$ or (37)] for $j=1,2$.

(iii) Specialization case 2 . Country 1 produces goods $x$ and $y$, and country 2 produces goods $y$, and $c$. Hence, $Y_{c 1}=0$ and $Y_{x 2}=0$. Demand for goods $c\left(c_{1}+c_{2}\right)$ determines $Y_{c 2}$ and $L_{c 2}$. The balance of $L_{2}$ is used for production of goods $Y$, thus $Y_{y 2}$ and $Y_{y 2}$ are given. Next, the unmet demand for goods $y\left(y_{1}+y_{2}\right)$ will be filled up by $Y_{y 1}$ which gives us $L_{y 1}$. Deducting this from $L_{1}$ decides $L_{x 1}$ which determines $Y_{x 1}$, given a number of $n$. Variables $r_{1}, r_{2}, w_{1}, w_{2}, p_{x}$, and $p_{y}$ are determined by equation (33) for $j=1$, equation (34) for $j=1,2$, (35) for $j=2$, and equation (36) [or (37)] for $j=1,2$.

(iv) Specialization case 3. Country 1 produces goods $x$, while country 2 produces goods $x, y$, and $c$. Therefore, $Y_{c 1}=0$ and $Y_{c 1}=0$. Similar to other cases, $Y_{x 2}, Y_{y 2}$, and $Y_{c 2}$ are determined, so does $Y_{x 1}$ for a given number of $n$. Variables $r_{1}, r_{2}, w_{1}, w_{2}, p_{x}$ and $p_{y}$ are determined by equation (33) for $j=1,2$, equations (34)-(35) for $j=2$, and equation (36) [or (37)] for $j=1,2$.

\section{NUMERICAL EXAMPLES}

31. To illustrate the behavior of the model, convergence paths are drawn with numerical examples using the following parameters.

$$
\begin{gathered}
\alpha=0.5, \quad \beta=0.4, \quad \gamma=0.3, \quad \theta=2, \quad \rho=0.02, \quad \delta=0.02, \\
\varphi=3, \quad \psi=5, \quad \sigma=0.995
\end{gathered}
$$

Labor force endowment is fixed at $L_{1}=0.37, L_{2}=0.63$. Fixed inputs for goods $x$ production are $K_{0}=L_{0}=0.001$.

32. With these assumptions, the steady state line is calculated as follows with the boundaries.

$$
K_{1}+K_{2}=27.2 \quad\left(10.1<K_{1}<14.6,12.6>K_{2}>17.1\right)
$$

With capital per labor $\left(k_{1}=K_{1} / L_{1}, k_{2}=K_{2} / L_{2}\right)$, the steady state line is expressed as below.

$$
0.37 * k_{1}+0.63 * k_{2}=27.2 \quad\left(27.2<k_{1}<39.4, \quad 20.1>k_{2}>27.2\right)
$$

33. Simulations show that there are two patterns of convergence to the steady state. If the combination of factor endowments of the countries allows the factor price equalization, which happens when the factor endowments are relatively similar between the countries, converge paths move towards the steady state line (Figure 4). The final location of the convergence pathes reaching on the steady state line depends on the initial endowments. The ratio between $k_{1}$ and $k_{2}$ is almost stable; hence, per labor capital of country 2 does not catch up with that of country 1 . After reaching the steady state line, the capital endowment stays at the point. The model does not have a mechanism for country 2 to further catch up with that of country 1 in terms of capital accumulation.

\footnotetext{
Obtained by inserting the expansion path into production function.
} 
Figure 4: Convergence Paths of Capital per Labor (Specialization Case)

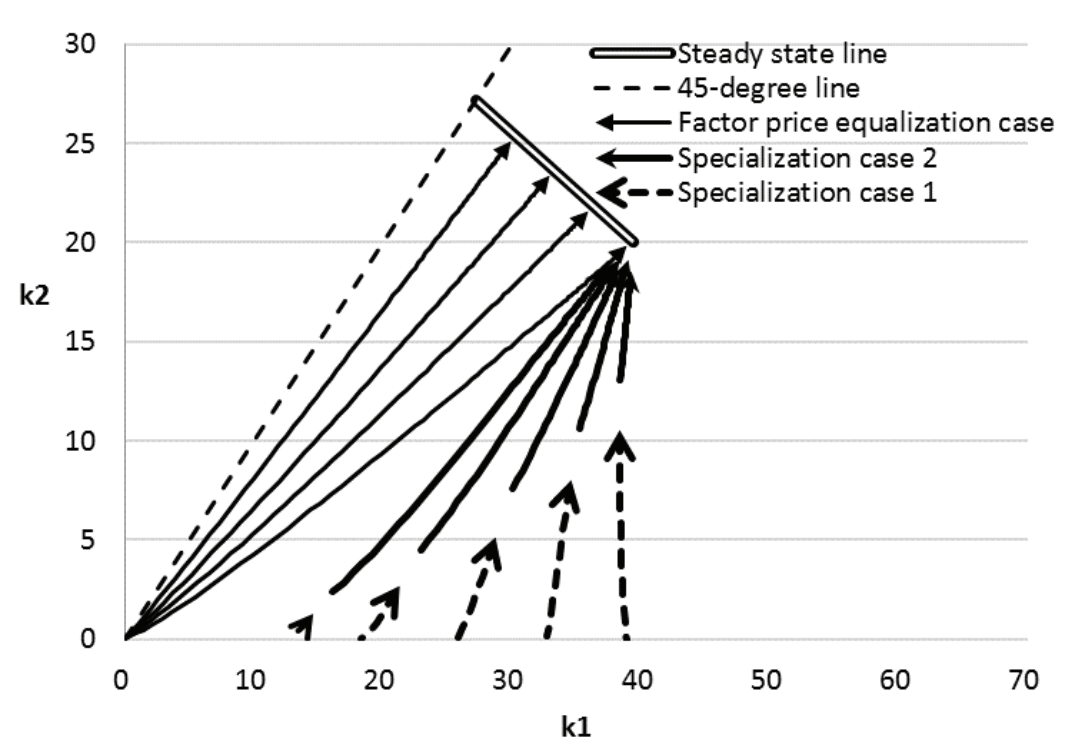

Source: Author.

34. If the government of country 2 intervenes in the capital-accumulation process and achieves investment beyond what the model determines, the convergence shifts to a higher path where country 2 will have higher per labor capital stock at the steady state. Country 1, on the other hand, will have lower capital stock per labor. Competition for higher per labor capital among the countries under the factor price equalization is thus a zero-sum game.

35. Convergence with specialized production emerges when factor endowments are relatively different between countries. In such cases, factor prices do not equalize. Convergence paths head to the lower boundary of the steady state line (Figure 4). Slope of convergence paths are steeper when original per labor capital endowments have larger difference. Per labor capital in country 2 catches up with that of country 1 to a certain extent (in terms of relative size of per labor capital), but the gap does not diminish entirely. Factor prices for capital and labor are different at the early stage of convergence (capital prices are higher, and labor prices are lower in country 2, which is capital-scarce and laborabundant). Factor prices fully equalize at the steady state (Figure 5).

36. At the steady state, gaps in per labor capital between country 1 and 2 are wider if the steady state is far from the 45-degree line (Table 1). Gaps are smaller in gross domestic product (GDP) per labor than those in per labor capital, and further smaller in per labor consumption. This is because country 1 has larger capital stock, hence they need to spend a larger share of its income for investment to cover its depreciation. On the other hand, country 2 has less burden to maintain the capital stock, and therefore, even if their income per labor is smaller, they can spend larger share of income for consumption. The gaps are largest at the lower boundary of the steady state. 
Figure 5: Dynamics of Economic Variables During Convergence

(Specialization Case)
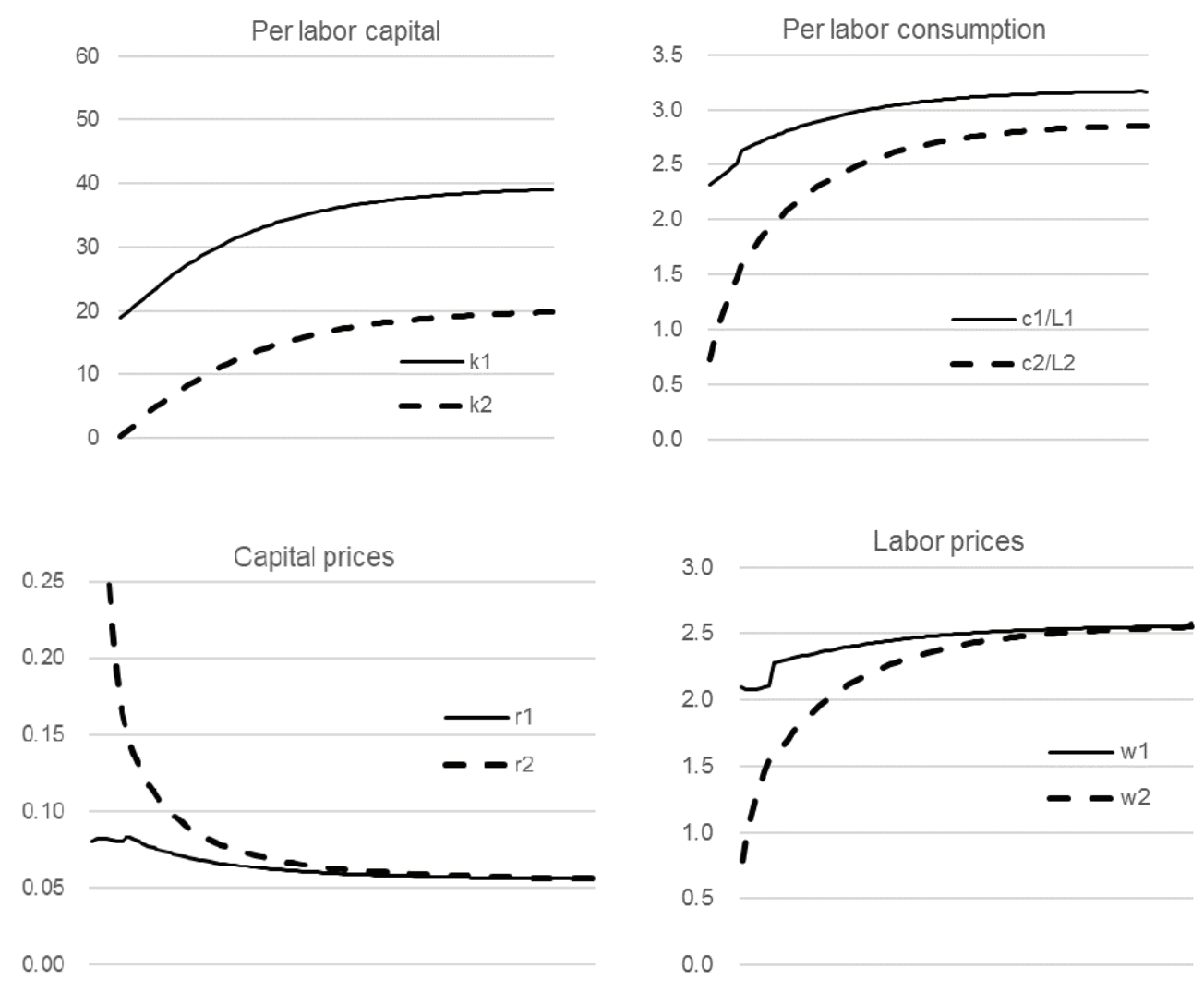

Source: Author.

Table 1: Status of Economy at Steady State

\begin{tabular}{|c|c|c|c|c|c|c|}
\hline & \multicolumn{2}{|c|}{$\begin{array}{l}\text { On the steady state line } \\
\qquad\left(k_{1}=33.3\right)\end{array}$} & \multicolumn{2}{|c|}{$\begin{array}{l}\text { On the steady state line } \\
\qquad\left(k_{1}=36.3\right)\end{array}$} & \multicolumn{2}{|c|}{$\begin{array}{l}\text { At the lower boundary of } \\
\text { steady state line }\left(k_{1}=39.4\right)\end{array}$} \\
\hline & Country 1 & Country 2 & Country 1 & Country 2 & Country 1 & Country 2 \\
\hline Per labor capital & 33.3 & 23.6 & 36.3 & 21.8 & 39.4 & 20.1 \\
\hline Per labor GDP & 4.4 & 3.9 & 4.6 & 3.8 & 4.8 & 3.7 \\
\hline Per labor consumption & 3.09 & 2.94 & 3.14 & 2.91 & 3.19 & 2.88 \\
\hline
\end{tabular}

GDP = gross domestic product.

Source: Author. 
37. Relative share of production capacity in country 2 against country 1 vis-a-vis the global demand for goods $x, y$, and $c$ decides industrialization in country 2 . If country 2 does not have sufficient factor endowments to produce goods c to meet the global demand, country 1 will also produce goods c; hence, production mix will be specialization case 1. If country 2 accumulates capital and acquires capacity to produce goods $c$ to meet its global demand, it will start producing goods $y$. If country 2 accumulates more capital to produce goods $c$ and $y$ to meet its global demand, it will start producing goods $x$. Figure 4 shows that convergence paths, which has specialization case 1 at the early stage of convergence, and case 2 near the steady state. Figure 6 illustrates the image of industrialization. ${ }^{2}$ On the demand side, share of investment is larger in the early stage of convergence because of capital accumulation, but it decreases as the economies moves close to the steady state. On the supply side, the production share of developing country expands during the convergence as it accumulates capital faster than the advanced country. When the share of developing country exceeds the demand for consumption goods, industrialization of developing country starts.

38. Simulations found that industrialization does not happen as a continuous structure change. There are transition periods shown as breaks between the convergence paths of specialization cases 1 and 2 (Figure 4). This is because the system of equations cannot generate a solution compatible with both cases 1 and 2 . If such solution exists, it should satisfy equations (32) and (33) for $j=1,2$ at the same time, but it is not possible. After country 1 stops producing goods $y$, country 2 needs to accumulate its capital further before it starts production of goods $y$. During the time, country 2 continues producing goods $c$ with excess production capacity, i.e., its market clearing condition is not met.

Figure 6: Image of Industrialization of Developing Country

\begin{tabular}{|c|c|c|c|}
\hline \multicolumn{2}{|c|}{ Global demand share } & \multicolumn{2}{|c|}{ Global supply share } \\
\hline $\begin{array}{l}\text { Investment } \\
\text { goods }(x, y)\end{array}$ & $\begin{array}{l}\text { Investment } \\
\text { goods }(x, y)\end{array}$ & $\begin{array}{l}\text { Advanced } \\
\text { country }\end{array}$ & $\begin{array}{l}\text { Advanced } \\
\text { country }\end{array}$ \\
\hline & & $\begin{array}{c}\text { Developing } \\
\text { country }\end{array}$ & \\
\hline Consumption & goods (c) & & \\
\hline goods (c) & & & $\begin{array}{c}\text { Developing } \\
\text { country }\end{array}$ \\
\hline $\begin{array}{l}\text { Early stage of } \\
\text { convergence }\end{array}$ & $\begin{array}{l}\text { Later stage of } \\
\text { convergence }\end{array}$ & $\begin{array}{l}\text { Later stage of } \\
\text { convergence }\end{array}$ & $\begin{array}{l}\text { Early stage of } \\
\text { Convergence }\end{array}$ \\
\hline
\end{tabular}

Source: Author.

\footnotetext{
2 The mechanism of industrialization explains the flying geese pattern of development in East Asia. As the share of developing countries increases in the global economy and exceeding the global share of consumption goods demand, counties with relatively higher per labor capital starts industrialization.
} 


\section{INTRODUCTION OF INTERNATIONAL CAPITAL MOBILITY}

39. This section introduces international capital mobility into the model. It is assumed that a part of capital stock in country $1(\Delta K)$ movesw to country 2 . Therefore, equation (26) is changed as follows.

$$
\begin{aligned}
n^{\frac{\sigma-1}{\sigma}} *\left(\frac{\alpha}{1-\alpha} * \frac{w_{j}}{r_{j}}\right)^{1-\alpha} * Y_{x j}+n_{j} * K_{0}+\left(p_{y}-\frac{p_{x}}{\psi}\right) * \frac{\beta}{r_{j}} * Y_{y j} & \\
& +\left(1-\frac{p_{x}}{\psi}\right) * \frac{\gamma}{r_{j}} * Y_{c j}=K_{j} \pm \Delta K
\end{aligned}
$$

where $-\Delta K$ for $j=1$ and $+\Delta K$ for $j=2$

40. The balance of payments is now explicitly included in the system of equations. To keep the equation simple, it is assumed that capital moves from country 1 to country 2 at the beginning of a period, and returns at the end of the period. As such, the capital mobility does not have impact on capital account for the period. Factor income will be transferred from country 2 to country 1 at the end of each period. Suppose that there is no change in gross international reserves, current account (trade balance and factor income) will also be balanced. Accordingly, the balance of payments will be described as follows.

$$
\begin{aligned}
& \quad p_{x} *\left(Y_{x j}-x_{j}\right)+p_{y} *\left(Y_{y j}-y_{j}\right)+\left(Y_{c j}-c_{j}\right) \pm r_{2} * \Delta \mathrm{K}=0 \\
& \text { where }-r_{2} * \Delta \mathrm{K} \text { for } j=1 \text { and }+r_{2} * \Delta K \text { for } j=2
\end{aligned}
$$

Thus, $\Delta K$ is added as an additional variable into the equation system, and equation (50) for one of the countries as an additional equation (when the balance of payments of a country is balanced, that of the other is also balanced automatically). Variables are determined so that factor price equalization holds, because capital moves until capital prices become the same.

41. Simulations with same parameters show that convergence of per labor capital does not happen with the mobile capital. Hence, large differences in per labor capital between countries remain (Figure 7). Note that per labor capital $\left(k_{1}, k_{2}\right)$ only includes those accumulated domestically and do not contain capital exported or imported from abroad. Convergence paths for factor price equalization cases are the same as before, because there will be no capital transfer between the two countries with equal capital prices. In case of the specialization case, per labor capital does not converge to the lower end of the steady state line, but to the extended part of the steady state line. Therefore, per labor capital grows almost proportionally in the two countries, i.e., country 2 does not catch up with country 1 (Figure 8). Gaps are larger when the steady state is located far from the lower boundary.

42. Foreign capital helps country 2 to industrialize at the earlier stage of its development. Under the capital mobility case, case 1 specialization does not appear anymore. Case 2 production (industrialization) is achieved even at the early stage of convergence. This would happen only if the production mix at the steady state follows case 2 .

43. Despite the large difference in per labor (domestic) capital, the gaps in per labor GDP and per labor consumption are limited. This is because domestic capital in country 2 is supplemented by the capital transfer from country 1 , and the total capital can generate higher level of GDP and consumption. Nevertheless, the gaps are larger than in the case without capital mobility. Capital transfer and payment for the capital (factor income transfer in the balance of payments) continues even at the steady state (Table 2). 


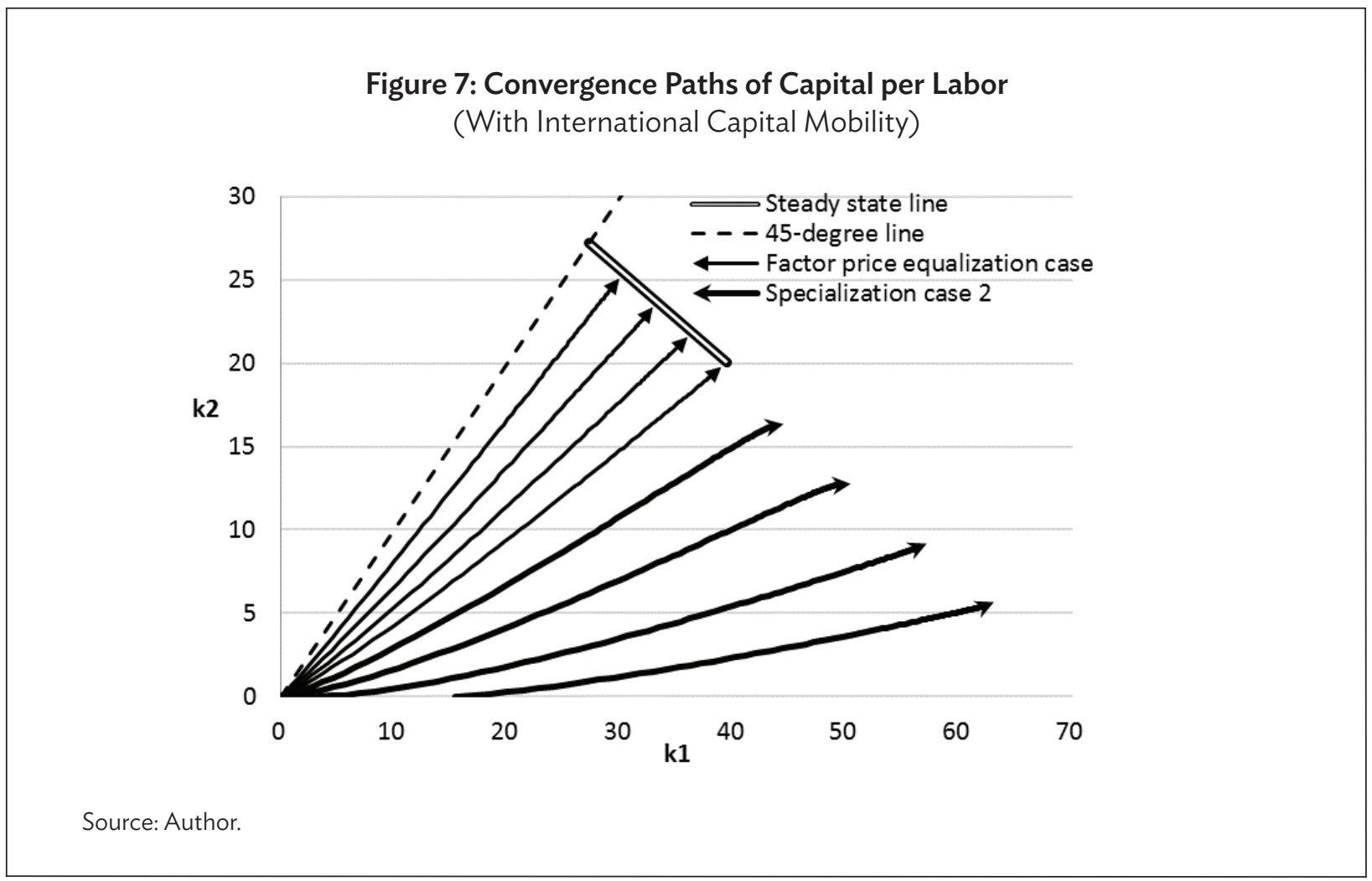

Table 2: Status of Economy at Steady State

(With International Capital Mobility)

\begin{tabular}{|c|c|c|c|c|c|c|}
\hline & \multicolumn{2}{|c|}{$\begin{array}{l}\text { At the lower boundary of } \\
\text { steady state line }\left(k_{1}=39.4\right)\end{array}$} & \multicolumn{2}{|c|}{$\begin{array}{l}\text { Beyond the steady state line } \\
\qquad\left(k_{1}=45.5\right)\end{array}$} & \multicolumn{2}{|c|}{$\begin{array}{l}\text { Beyond the steady state line } \\
\qquad\left(k_{1}=51.6\right)\end{array}$} \\
\hline & Country 1 & Country 2 & Country 1 & Country 2 & Country 1 & Country 2 \\
\hline Per labor capital & 39.4 & 20.1 & 45.5 & 16.5 & 51.6 & 12.9 \\
\hline Per labor GDP & 4.8 & 3.7 & 5.1 & 3.5 & 5.4 & 3.3 \\
\hline Per labor consumption & 3.19 & 2.88 & 3.28 & 2.82 & 3.38 & 2.77 \\
\hline Per labor capital transfer & 0 & 0 & -6.1 & 3.6 & -12.2 & 7.2 \\
\hline
\end{tabular}

Source: Author. 


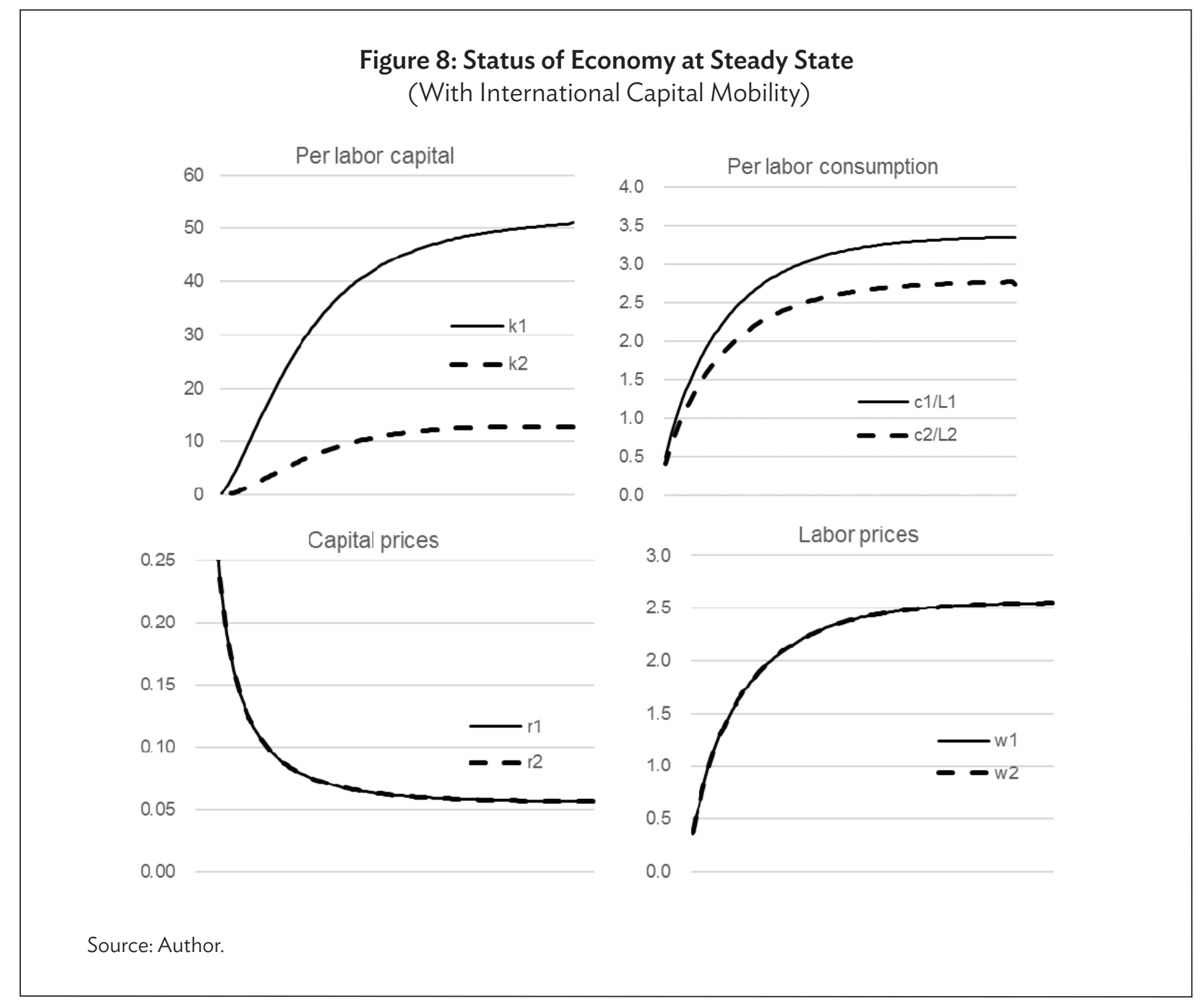

\section{CONCLUSIONS}

44. This study showed that the industrialization of developing countries happens when their share of production in the global economy exceeds the global demand for consumption goods. It is not determined by income level of developing countries, and not all of developing countries can industrialize. It also showed that industrialization does not start as a continuous structure change, but there will be a transition period when market clearing conditions are not met. This would call for policy intervention to support industrialization for those countries that have the potential.

45. The study simulated convergence paths of per labor capital where initial factor endowments are relatively different between countries. It is relevant to developing and advanced countries. In such cases, factor prices do not equalize (Heckscher-Ohlin theory does not hold), and countries specialize in the production of one or two goods. Simulations indicate that developing countries catch up with advanced countries to a certain extent (in terms of relative size of per labor capital), but the gap does not diminish entirely even at the steady state. Gaps in GDP per labor is smaller than those in per labor capital, and further smaller in per labor consumption. This is because countries with less capital stock have less burden of replacement investment, hence they can spend a larger share of their income for consumption. 
46. If capital becomes mobile between advanced and developing countries, developing countries have a chance to industrialize immediately by introducing foreign capital, if the industrialization condition at the steady state is met. Since such developing countries do not accumulate their own capital as much as in the case without the capital mobility, they will continue depending on foreign capital even at the steady state. The gaps in per labor GDP and per labor consumption between developing and advanced countries at the steady state will be larger compared to the case without capital mobility.

47. This paper focused on capital accumulation, which is only a part of economic growth. The role of total factor productivity, which is another important source of growth, is not incorporated. This limitation makes the model silent on the development beyond the steady state. Further, the model assumes that capital-labor ratio is the only factor to determine trade pattern. Comparative advantages from geographic location often play a more important role, but this aspect is not considered. Therefore, the purpose of this study is limited to propose a general framework to analyze capital accumulation and industrialization. It does not provide any policy recommendation for a specific country. 


\section{REFERENCES}

Atkeson, A., and P. J. Kehoe. 2000. Paths of Development for Early- and Late-Bloomers in a Dynamic Heckscher-Ohlin Model. Research Department Staff Report 256. Federal Reserve Bank of Minneapolis.

Bajona, C., and T. J. Kehoe. 2006. Trade, Growth, and Convergence in a Dynamic Heckscher-Ohlin Model. NBER Working Paper Series. Working Paper 12567. October.

-_- 2010. Trade, Growth, and Convergence in a Dynamic Heckscher-Ohlin Model. Research Department Staff Report 378. Federal Reserve Bank of Minneapolis.

Chen, Z. 1992. Long-Run Equilibria in a Dynamic Heckscher-Ohlin Model. The Canadian Journal of Economics / Revue Canadienne d'Economique. Vol. 25, No. 4 (November). pp. 923-943.

Cuñat, A., and M. Maffezzoli. 2004. Neoclassical Growth and Commodity Trade. Review of Economic Dynamics. Volume 7, Issue 3. July. pp. 707-736.

Deardorif, A. V. 2002. Introduction to Two-Cone HO Equilibrium. 5 July. University of Michigan.

Fujita, M., P. Krugman, and A. J. Venables. 1999. The Spatial Economy - Cities, Regions, and International Trade. The MIT Press.

Gaitan, B., and T. Roe. 2007. Path Interdependence among Early and Late Bloomers in a Dynamic Heckscher-Ohlin Model. Economic Development Center, Bulletin Number 07-1. April.

Schott, P. K. 2003. One Size Fits All? Heckscher-Ohlin Specialization in Global Production. The American Economic Review. Vol. 93, No. 3. June. pp. 686-708.

Trefler, D. 1993. International Factor Price Differences: Leontief was Right! The Journal of Political Economy. Volume 101. Issue 6. December 1996: pp. 961-987.

Ventura, J. 1997. Growth and Interdependence. The Quarterly Journal of Economics. Vol. 112, No. 1. February. pp. 57-84. 


\section{APPENDIX: RELATIONSHIP BETWEEN VARIETIES AND SYNTHETIC GOODS}

Varieties $x_{i}$ are combined into a synthetic goods $x$ following the constant elasticity of substitution function in equation (1), minimizing the cost for attaining the synthetic goods. Given the prices of varieties $\left(p_{x i}\right)$ and the volume of the synthesis goods supply $\left(Y_{x i}\right)$, it is described as the following minimization problem.

$$
\min \int_{0}^{\infty} p_{x i} * Y_{x i} d i \quad \text { s.t. } \quad Y_{x}=\left(\int_{0}^{n} Y_{x i}{ }^{\sigma} d i\right)^{\frac{1}{\sigma}}
$$

First order condition leads to the following equation for any pair of varieties $i 1$ and $i 2$.

$$
\frac{Y_{x i 1}}{Y_{x i 2}}=\left(\frac{p_{x i 1}}{p_{x i 2}}\right)^{1 /(\sigma-1)}
$$

Substituting the above equation into the constraint in (A1) for variety $i 1$ gives the following equation, which indicates the expenditure on variety $i 2$.

$$
p_{x i 2} * Y_{x i 2}=\frac{p_{x i 2} \sigma /(\sigma-1)}{\left\{\int_{0}^{n} p_{x i 1} \sigma /(\sigma-1) d i\right\}^{1 / \sigma}} * Y_{x}
$$

Integrating the equation over $i 2$ gives the expenditure for the synthetic goods $Y_{x}$.

$$
\int_{0}^{n} p_{x i 2} * Y_{x i 2} d i 2=\left\{\int_{0}^{n} p_{x i}^{\sigma /(\sigma-1)} d i\right\}^{(\sigma-1) / \sigma} * Y_{x}
$$

The term infront of $Y_{x}$ on the right-hand side can be interpreted as a price index of the synthetic goods $\left(p_{x}\right)$.

$$
p_{x}=\left\{\int_{0}^{n} p_{x i}^{\sigma /(\sigma-1)} d i\right\}^{(\sigma-1) / \sigma}
$$

Combining with equation (A3) leads to

$$
Y_{x i}=\left(\frac{p_{x}}{p_{x i}}\right)^{1 /(\sigma-1)} * Y_{x}
$$

By differentiating the equation with $p_{x i}$, following relations is obtained.

$$
\frac{\partial Y_{x i}}{\partial p_{x i}}=\frac{1}{\sigma-1} * \frac{Y_{x i}}{p_{x i}}
$$




\section{Industrialization of Developing Countries in a Multicountry, Multisector Capital Accumulation Model}

This working paper shows that developing countries industrialize, or start producing investment goods, when their relative share in global production becomes larger than the global demand for consumption goods. Industrialization is simulated in a capital accumulation model with two countries, three goods, and two factors. The model accommodates trade relations where countries specialize in producing certain goods and includes production under monopolistic competition and intermediate inputs. Capital mobility across the border can facilitate the industrialization of developing countries. They will continue borrowing capital from advanced countries even at the steady state.

\section{About the Asian Development Bank}

ADB is committed to achieving a prosperous, inclusive, resilient, and sustainable Asia and the Pacific, while sustaining its efforts to eradicate extreme poverty. Established in 1966, it is owned by 67 members48 from the region. Its main instruments for helping its developing member countries are policy dialogue, loans, equity investments, guarantees, grants, and technical assistance. 